\title{
Media Pembelajaran Berbasis Edmodo Mengenai Materi Virus
}

\section{Agus Maryanto ${ }^{*}$, Ardi ${ }^{2}$, Heffi Alberida ${ }^{3}$}

1,2,3 Universitas Negeri Padang, Padang, Indonesia

\section{ART ICLE INF O}

Article history:

Received May 07, 2021

Revised May 10, 2021

Accepted August 28, 2021

Available online October 25, 2021

Kata Kunci:

E-learning, Edmodo, Virus

Keywords:

E-learning, Edmodo, Virus

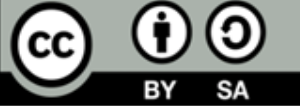

This is an open access article under the CC BY-SA license.

Copyright (C) 2021 by Author. Published by Universitas Pendidikan Ganesha.

\begin{abstract}
A B S T R A K
Guru berperan sangat penting dalam memilih dan menggunakan media yang digunakan untuk membantu proses pembelajaran namun masih banyak ditemui kurangnya media pembelajaran yang digunakan oleh guru, sehingga siswa kurang mampu memahami materi pembelajaran secara maksimal. Penelitian ini bertujuan untuk menganalisis validitas media pembelajaran e-learning berbasis edmodo tentang materi virus untuk peserta didik. Jenis penelitian ini adalah penelitian Research and Development $(R \& D)$ dengan menggunakan Model 4D. Subjek penelitian ini adalah dua orang dosen dan satu orang guru sebagai validator penggunaan e-learning. Teknik analisis data yaitu analisis deskriptif kualitatif dan deskriptif kuantitatif. Tahap pengujian kelayakan media ini dilakukan dengan cara validasi produk oleh pakar. Hasil validasi menunjukkan nilai rata-rata 92,56 dengan kategori sangat valid. Hasil validasi ini ditinjau dari beberapa kategori yaitu aspek kelayakan isi, aspek kebahasaan, aspek sajian dan aspek kegrafikan. Instrumen yang digunakan untuk mengumpulkan data dalam penelitian ini yaitu angket validitas. Implikasi penelitian ini dapat membuat siswa menjadi tertarik dan lebih mudah mengerti dengan materi yang diberikan. Berdasarkan hasil yang diperoleh dapat disimpulkan bahwa media pembelajaran Berbasis Edmodo ini baik dan layak digunakan dalam proses pembelajaran.
\end{abstract}

\section{A B S T R A C T}

Teachers play a vital role in choosing and using the media used to help the learning process, but there is still much lack of learning media used by teachers, so students can less understand the learning material optimally. This study aims to analyze the validity of the Edmodo-based e-learning media about viral material for students. This type of research is Research and Development (R\&D) research using the 4D Model. The subjects of this study were two lecturers and one teacher as validators for elearning. The data analysis technique is the descriptive qualitative analysis and descriptive quantitative. The media feasibility testing phase is carried out using product validation by experts. The validation results show an average of 92.56, with a very good category. The validation results are reviewed from several categories, namely aspects of content feasibility, linguistic aspects, presentation aspects and visual aspects. The instrument used to collect data in this study is a validity questionnaire. The implications of this research can make students interested and easier to understand the material provided. Based on the results obtained, it can be concluded that the Edmodo-based learning media is reasonable and feasible to use in the learning process.

\section{PENDAHULUAN}

Pembelajaran adalah kegiatan yang dilakukan oleh guru dan dan siswa bersama komponenkomponen yang terkait yang bertujuan untuk mencapai tujuan pendidikan guna menjadi pribadi yang lebih baik (Sofnidar \& Yuliana, 2018; Virgiana \& Wasitohadi, 2016). Saat ini pembelajaran dilaksanakan berdasarkan kurikulum 2013 berorientasi kepada peserta didik atau biasa disebut student center (Kurniaman \& Noviana, 2017; Lestari, 2018; Retnawati et al., 2016). Kurikulum 2013 diterapkan dengan pembelajaran tematik integratif yang pembelajarannya memberikan makna yang utuh kepada peserta didik. Sehingga siswa dapat bersaing dengan pendidikan dunia yang menuntut pemikiran yang 
berkualitas (Mulyadin, 2016; Mustikaningrum et al., 2020). Pembelajaran dengan kurikulum dapat diterapkan salah satunya dengan memanfaatkan Ilmu Pengetahuan dan Teknologi. Seiring berjalannya waktu perkembangan Teknologi Informasi (TI) dijadikan sebagai solusi dalam membantu proses pembelajaran (Boyd, 2019; Bravo et al., 2015; Weng \& Chen, 2020). TI dalam membantu pembelajaran biologi, dapat memperjelas pemahaman agar tidak terlalu kaku, mengatasi keterbatasan hambatan ruang, waktu, lalu mengatasi sikap pasif peserta didik menjadi aktif serta dapat membantu munculnya persamaan konsep belajar peserta didik (Restiyani, 2014). Selain itu TI juga dapat dijadikan solusi dalam mengatasi sistem pembelajaran dalam jaringan (daring) ditengah permasalahan pandemi corona virus disease 19 (COVID-19) yang terjadi sekarang ini.

Pembelajaran daring adalah pembelajaran yang dilaksankan dengan memanfaatkan teknologi dan internet (Fauzi \& Sastra Khusuma, 2020; Windhiyana, 2020). Pembelajaran daring dilaksanakan guna mencegah penularan covid-19. Dengan dilaksanakan pembelajarn daring diharapkan siswa menerima haknya untuk tetap belajar. Pembelajaran daring biasanya dilaksankan dengan melalui whatsapp, google classroom, dan google meet (Mali \& Lim, 2021; Maqableh \& Alia, 2021; Mustakim et al., 2021). Dalam pembelajaran online guru juga dituntut untuk dapat memanfaatkan media pembelajaran secara kreatif agar tercapainya tujuan pembelajaran secara maksimal (Hasanah et al., 2018; Heru \& Yuliani, 2020; Pratiwi et al., 2017). Media pembelajaran adalah alat yang digunakan oleh guru untuk memperjelas makna yang tersirat dalam materi pembelajaran (Jogezai et al., 2021; Saputra et al., 2021; Suni Astini, 2020). Dengan menggunakan media pembelajaran yang sesuai dengan kodisi dan situasi, maka siswa akan lebih mudah memahami materi yang diajarkan (Faizah et al., 2021; Saputra et al., 2021).

Namun yang terjadi dilapangan beberapa siswa hasil belajarnya masih rendah yang disebabkan oleh kurangnya media pembelajaran yang memfasilitasi siswa dalam belajar (Ahdan et al., 2020; Ferdiansyah et al., 2020; Junaedi, 2021). Kurangnya media pembelajaran ini berdampak pada pemahaman materi pembelajaran yang rendah (Ahmad \& Mustika, 2021; Herayanti et al., 2017). Pada pembelajarn daring siswa juga mulai bosan dalam belajar karena rendahnya interaksi antara guru dan siswa (Anugrahana, 2020; Suyanti et al., 2021). Berdasarkan hasil wawancara dengan salah seorang Guru biologi SMA Pembangunan Laboratorium Universitas Negeri Padang, terungkap bahwa pada pembelajaran biologi membutuhkan suatu media yang lebih nyata, dan dapat menunjang proses pembelajaran di tengah pembelajaran daring. karena dengan media siswa akan lebih mudah untuk memahami materi yang disampaikan oleh guru. Oleh sebab itu, maka diperlukan pengembangan media pembelajaran yang dapat membantu guru dan mudah dipahami sehingga menarik minat belajar siswa agar proses pembelajaran menjadi lebih efektif. Media pembelajaran merupakan alat bantu yang digunakan oleh guru untuk menyampaikan materi agar tujuan pembelajaran dapat tercapai secara maksimal (Pramana et al., 2018; Tegeh et al., 2019). Guru harus bisa merancang dan memilih media yang inovatif sehingga dapat menumbuhkan semangat dan motivasi siswa dalam belajar (Azimi et al., 2017; Mustofa \& Syafi'ah, 2018). Salah satu pembelajaran yang membutuhkan media yaitu E-learning. E-learning adalah suatu sistem operasi yang menggunakan jaringan komputer atau internet dan sebagai media pembantu dalam pembelajaran secara virtual (Atiyah et al., 2020; Sadikin \& Hakim, 2019; Zhang et al., 2016). Selaras dengan itu e-learning juga memberikan manfaat kepada guru, dimana guru dapat mengawasi dan menyampaikan pembelajaran lebih efisien dan efektif. Guru dapat mengirimkan video, animasi serta gambar yang bertujuan dalam meningkatkan pemahaman peserta didik pada materi yang sedang di sampaikan (Fatimah \& Mahmudah, 2020; Wardoyo \& Article, 2016). Salah satu media pembelajaran e-learning yaitu dengan menggunakan platform belajar yaitu edmodo.

Edmodo merupakan suatu e-learning alternatif yang mudah mengaplikasikannya, dan ditujukan pada kebutuhan peserta didik dengan harapan peserta didik dapat berkolaborasi dan mandiri dalam belajar (Sari et al., 2019; Yanti et al., 2019). Selain itu edmodo juga mendukung kemudahan dalam pembelajaran karena peserta didik dapat memahami materi, karena dilengkapi dengan beberapa media pendukung seperti video, gambar dan animasi (Helsa \& Kenedi, 2019; I. Jayusman \& Shavab, 2020; Qingqing, 2016). Edmodo yaitu suatu platform belajar dan bertujuan untuk membantu proses pembelajaran termasuk memberikan tugas, penilaian, polling, peringatan dan agenda pembelajaran kedepannya (Hatip et al., 2019; Widyaningrum et al., 2020). Oleh karena itu edmodo bisa digunakan dalam pembelajaran, termasuk pembelajaran biologi. Penelitian sebelumnya menyatakan bahwa media pembelajaran e-learning berbasis edmodo pada materi sistem gerak dapat dikatakan layak untuk digunakan dalam proses pembelajaran (Balasubramanian et al., 2014; Utami et al., 2021). Pemanfaatan media pembelajaran e-learning berbasis edmodo dapat meningkatkan efisiensi, keterbatasan ruang dan waktu, dapat digunakan skala luas dengan kreativitas dan manajemen guru dalam mengelola belajar mengajar virtual (Haruna et al., 2021; Sefriani et al., 2021). Temuan penelitian lain juga menunjukkan bahwa e-learning berbasis edmodo dapat dimanfaatkan untuk meningkatkan minat dan memfasilitasi pembelajaran interaktif yang mendukung pemahaman peserta didik (Farman \& Chairuddin, 2020; 
Solehana et al., 2019). Penelitian ini bertujuan untuk menganalisis validitas Media Pembelajaran $E$ learning berbasis Edmodo Tentang Materi Virus untuk Peserta didik Kelas X SMA/MA. Diharapkan Elearning berbasis Edmodo dapat memudahkan siswa dalam belajar online.

\section{METODE}

Jenis penelitian ini adalah penelitian pengembangan Reseach And Development (R \& D) dengan menggunakan model 4-D. Pada penelitian ini dilakukan tiga tahapan pengembangan saja yaitu tahap pendefinisian (define), perancangan (design), dan pengembangan (develop), sedangkan tahap penyebaran (desseminate) tidak dilakukan karena keterbatasan waktu dan biaya. Penelitian ini akan dilakukan di Fakultas Matematika dan Ilmu Pengetahuan Alam (FMIPA) Universitas Negeri Padang (UNP) dan SMA Pembangunan Laboratorium Universitas Negeri Padang. Objek penelitian ini adalah Media Pembelajaran E-learning berbasis Edmodo tentang Materi Virus untuk Peserta didik kelas X SMA Pembangunan Laboratorium Universitas Negeri Padang. Subjek uji coba penelitian ini divalidasi oleh 2 orang dosen Jurusan Biologi dan 1 orang guru biologi SMA Pembangunan Laboratorium Universitas Negeri Padang.

Instrumen yang digunakan untuk mengumpulkan data dalam penelitian ini yaitu angket validitas. Angket validitas digunakan untuk mengetahui apakah yang telah dirancang valid atau tidak. Angket validitas yang digunakan terdiri dari beberapa komponen penilaian. Hal yang dinilai oleh pakar mencakup komponen kelayakan isi, komponen kebahasaan, komponen penyajian, dan komponen kegrafikaan. Analisis validasi e-learning dengan beberapa langkah berikut: 1) Memberikan skor jawaban dengan empat alternatif jawaban yang disusun menurut skala Likert yang dimodifikasi dari (Riduwan, 2012). Menentukan skor tertinggi, 3) Menentukan jumlah skor dari masing-masing validator dengan menjumlahkan semua skor yang diperoleh dari masing-masing indikator, 4) Menentukan skor yang diperoleh dengan menjumlahkan skor dari masing- masing validator, 5) Menentukan nilai validasi 6) Memberikan penilaian validitas dengan kriteria yang telah dimodifikasi sesuai dengan penilaian validitas (Purwanto, 2009).

\section{HASIL DAN PEMBAHASAN}

\section{Hasil}

Tahap Define (Pendefenisian). Analisis awal akhir dilaksanakan untuk menentukan masalah utama yang dihadapi oleh peserta didik dan guru. Peneliti melakukan observasi di SMA Pembangunan Laboratorium Universitas Negeri Padang dengan melakukan wawancara kepada salah seorang guru Biologi mengungkapkan bahwa sistem pembelajaran yang diterapkan sudah mengacu pada standar kurikulum 2013 namun dalam pelaksanaannya masih belum maksimal karena guru masih monoton dan perlu adanya suatu pembelajaran yang lebih variasi dengan menggunakan media pembelajaran penunjang pembelajaran peserta didik yaitu E-learning. Keterbatasan waktu dan banyaknya materi pembelajaran membuat kurang maksimalnya penyampaian materi sehingga indikator pencapaian kurang dapat tercapai. Berdasarkan analisis peserta didik dari hasil observasi kepada peserta didik, didapatkan bahwa peserta didik masih kesulitan memvisualisasikan konsep konsep pada materi pembelajaran. Penyajian materi pembelajaran dari guru harus bisa meberikan meningkatkan perkembangan psikomotor peserta didik dalam memahami gambar pada materi pembelajaran. Dalam hal ini peserta didik harus mampu memvisualisasikan materi pembelajaran agar konsep materi yang diterima peserta didik dapat mengembangkan psikomotor. Oleh sebab itu dengan menggunakan media E-learning dapat membantu peserta didik mengembangan kemampuan psikomotor. Analisis tugas dilakukan untuk menentukan materi yang akan disajikan kepada peserta didik. Analisis ini mencakup analisis struktur isi, analisis konsep dan perumusan tujuan pembelajaran.

Tahap Design (Perancangan). Pada tahap ini dilakukan penyiapan prototype dari media pembelajaran e-learning berbasis edmodo. Perancangan materi pembelajaran dan media dirancang harus sesuai dengan konsep konsep utama dan standar kurikulum 2013. Langkah-langkah pada tahap ini sebagi berikut. Pertama, pemilihan media. Media pembelajaran e-learning berbasis edmodo tentang materi virus. Perancangan materi pembelajaran dan media dirancang harus sesuai dengan konsep konsep utama virus. Kedua, perancangan Bahan Ajar. Perancangan bahan ajar tentang materi virus, isi dari bahan ajar berasal dari beberapa sumber yaitu buku biologi SMA dan dari hasil penelitian yang relevan pada materi virus. Ketiga, perancangan Soal. Soal pada media pembelajaran e-learning ini dirancang berdasarkan kisi-kisi soal yang dibuat dari pengembangan indikator pembelajaran materi virus. Total soal yang di buat pada materi virus yakni 25 soal bertipe multiple choice dari 3 kali pertemuan. Keempat, Perancangan Lembar Kerja Peserta Didik (LKPD). Perancangan lembar kerja peserta didik di buat dengan menggunakan microsoft word 2007 dan berdasarkan pada indikator pencapaian kompetensi materi virus. Lembar kerja 
peserta didik dibuat sesuai pertemuan yaitu 3 kali pertemuan dan di convert ke format pdf. Kelima, Pemilihan Gambar dan Video. Pemilihan gambar dan video yang terdapat pada media, berdasarkan fungsinya untuk mendukung pembelajaran yang didapatkan dari berbagai sumber buku ajar materi virus dan secara online. Pada masing-masing gambar dan video yang dirancang dilampirkan sumber yang relevan. Keenam, pemilihan Modul pada Materi Virus. Modul pada materi virus telah mendapat persetujuan sebelumnya. Modul pada media pembelajaran e-learning ini disesuaikan dengan pertemuan pembelajaran yaitu 3 kali pertemuan. Tahap Develop (Pengembangan). Pada tahap ini dilakukan pengembangan produk. Setelah produk dikembangkan selanjutnya yaitu validasi e-learning. Validasi $e$ learning dilakukan oleh 2 orang dosen jurusan Biologi FMIPA UNP, 1 orang guru biologi dengan menggunakan angket validitas. Hasil penelitian pada tahap validitas dapat dilihat pada Tabel 1.

Tabel 1. Hasil Uji Validitas

\begin{tabular}{|c|c|c|c|c|}
\hline \multirow{2}{*}{ No } & \multirow{2}{*}{ Aspek Penilaian } & \multicolumn{3}{|c|}{ Validator } \\
\hline & & Validator I & Validator II & Validator III \\
\hline 1. & Kelayakan Isi & 92,50 (Sangat Valid) & 97,50 (Sangat Valid) & 97,50 (Sangat Valid) \\
\hline 2. & Kebahasaan & $85,00($ Valid $)$ & 90,00 (Sangat Valid) & $\begin{array}{c}90,00((\text { Sangat } \\
\text { Valid })\end{array}$ \\
\hline 3. & Penyajian & 91,66 (Sangat Valid) & 95,83 (Sangat Valid) & 91,66 (Sangat Valid) \\
\hline 4. & Kegrafikaan & 95,83 (Sangat Valid) & 91,66 (Sangat Valid) & $\begin{array}{c}91,66 \text { ( Sangat } \\
\text { Valid) }\end{array}$ \\
\hline \multicolumn{2}{|c|}{ Rata-rata } & 91,24 (Sangat Valid) & 93,74 (Sangat Valid) & $\begin{array}{c}92,70 \text { (Sangat } \\
\text { Valid) }\end{array}$ \\
\hline \multicolumn{2}{|c|}{ Nilai Validitas } & \multicolumn{3}{|c|}{ 92,56 ( Sangat Valid) } \\
\hline
\end{tabular}

Berdasarkan hasil analisis data, terungkap bahwa validasi e-learning berbasis edmodo yang dikembangkan dapat dikatakan sangat valid dengan rata-rata 92,56\%, karena dapat dinilai dari berbagai kategori penilaian. Ada 4 kategori yang dinilai dari media pembelajaran e-learning berbasis edmodo, yaitu aspek isi yang dimuat, aspek kebahasaan yang digunakan, aspek sajian serta aspek kegrafikan atau tampilannya. Dalam pengembangannya e-learning berbasis edmodo telah mengalami revisi berdasarkan dari saran-saran validator.

\section{Pembahasan}

Berdasarkan dari hasil analisis data uji validitas maka uji validitas media pembelajaran e-learning berbasis edmodo dari 4 aspek yang diniliai mempunyai indikator penilaiannya nya masing masing sesuai kebutuhan. Untuk mengetahui bahwa suatu media itu layak maka harus dilakukan suatu penilaian yang nantinya akan memberikan gambaran bahwa media pembelajaran tersebut layak untuk digunakan pada proses pembelajaran (Hanifah et al., 2019; Haruna et al., 2021; Iyus Jayusman \& Shavab, 2020). Ditinjau dari segi aspek kelayakan isi media yang dikembangkan terkategori sangat valid dengan nilai 95,83\%. Penilaian uji validitas pada media pembelajaran yaitu aspek kelayakan isi dilihat dari tujuan dan standar dari pembelajaran, keterkaitan media dengan konsep materi, kebutuhan media pembelajaran yang akan digunakan, dan kebutuhan dari peserta didik, serta dilihat dari berbagai nilai-nilai yaitu nilai pengetahuan, sosial dan moralitas pada modul dan Lembar Kerja Peserta Didik (LKPD) yang diisikan pada media tersebut. Oleh sebab itu kelayakan isi harus memenuhi kriteria yang diharapkan agar nantinya media yang dihasilkan sesuai (Farman \& Chairuddin, 2020; Utami et al., 2021). format kelayakan suatu isi media pembelajaran mencapai valid harus sesuai dengan tujuan pembelajaran, materi pembelajaran serta taraf berfikir peserta didik.

Penilaian pada aspek kebahasaan media pembelajaran e-learning berbasis edmodo dinyatakan valid dengan nilai 88,33\%. Hal ini menunjukkan bahwa media pembelajaran e-learning yang dikembangkan sudah menggunakan bahasa yang mudah dipahami pada materi pembelajaran (Miraza et al., 2018; Sari et al., 2019; Yanti et al., 2019). Selain itu bahasa yang digunakan telah sesuai dengan acuan bahasa Indonesia yang tepat, serta mengunakan bahasa yang tepat dan efektif, sesuai dengan perkembangan pemikiran peserta didik agar nantinya bisa memahami informasi yang disampaikan (Putri et al., 2021; Sudewa et al., 2021; Suriadhi et al., 2014). Penilaian pada aspek sajian berdasarkan angket validitas media pembelajaran e-learning berbasis edmodo dengan nilai 93,05\% berkategori sangat valid. Hal ini berarti sudah tercapainya komponen penyajian materi, tujuan pembelajaran yang disampaikan, informasi pada materi dan urutan teks serta gambar yang terkait pada materi dapat memotivasi peserta didik. Media yang dipakai pada kegiatan belajar harus memiliki tingkat penyajian yang valid sehingga 
akan lebih mudah dipahami, dan nanntinya akan memotivasi peserta didik dalam pembelajaran (Hatip et al., 2019; Miraza et al., 2018; Windhiyana, 2020).

Ditinjau dari aspek kegrafikan media pembelajaran e-learning berbasis edmodo yang dikembangkan terkategori sangat valid dengan nilai 93,05\%. Hal ini menandakan bahwa penggunaan font, keserasian warna tampilan media, kesesuaian ukuran dan dimensi media sudah sesuai (Khamparia \& Pandey, 2017; Kurtz et al., 2014; Maatuk et al., 2021). Tampilan gambar pada media harus dinyatakan valid karena tampilan dapat mendukung pemahaman materi pada bahan ajar. Indikator penilaian aspek kegrafikan adalah keseimbangan gambar dalam media pembelajaran yang diisikan, Keseimbangan tampilan warna pada gambar, gambar yang terdapat pada media harus sesuai dengan materi, dan urutan dari gambar dan teks harus saling terkait (Elfeky et al., 2020; Pustika, 2020; Yaniawati, 2013). Secara keseluruhan media pembelajaran e-learning berbasis edmodo tentang materi virus untuk peserta didik kelas X SMA/MA berkategori sangat valid dengan rata-rata 93,39\%. Hal ini berarti bahwa validitas media pembelajaran ini sangat valid dan telah memenuhi syarat untuk dijadikan alat bantu dalam mencapai tujuan pembelajaran. Materi akan lebih mudah dipahami serta mampu meningkatkan motivasi belajar siswa apabila media pembelajaran tersebut valid (Angga et al., 2020; Sunarti et al., 2016). Hasil penelitian penelitian sebelumnya menunjukkan bahwa media pembelajaran e-learning berbasis edmodo layak untuk digunakan dalam proses pembelajaran (Hatip et al., 2019; Putri et al., 2021; Sudewa et al., 2021). Temuan penelitian lainnya juga menyatakan bahwa E-learning sangat cocok digunakan ditengah pandemic covid19 sehingga tujuan pembelajaran dapat tercapai (Adedoyin \& Soykan, 2020; Mpungose, 2021; Shaik Alavudeen et al., 2021). Sehingga dengan adanya media pembelajaran e-learning berbasis edmodo diharpak mampu meningkatkan semangat dan hasil belajar siswa.

\section{SIMPULAN}

Berdasarkan dari hasil uji validitas media pembelajaran e-learning berbasis edmodo tentang materi virus untuk peserta didik kelas X SMA/MA dinyatakan sangat valid. Disimpulkan bahwa media pembelajaran e-learning berbasis Edmodo dapat digunakan dalam proses pembelajaran sehingga tujuan pembelajaran dapat tercapai dengan maksimal.

\section{DAFTAR RUJUKAN}

Adedoyin, O. B., \& Soykan, E. (2020). COVID-19 Pandemic and Online Learning: The Challenges and Opportunities. Interactive Learning Environments, 29(8), 1-14. https://doi.org/10.1080/10494820.2020.1813180.

Ahdan, S., Putri, A. R., \& Sucipto, A. (2020). Aplikasi M-Learning Sebagai Media Pembelajaran Conversation Pada Homey English. Sistemasi, 9(3), 493. https://doi.org/10.32520/stmsi.v9i3.884.

Ahmad, F., \& Mustika, D. (2021). Problematika Guru Dalam Menerapkan Media pada Pembelajaran Kelas Rendah Di Sekolah Dasar. Jurnal Basicedu, 5(4), 2008-2014. https://doi.org/10.31004/basicedu.v5i4.1056.

Angga, P. M. W., Sudarma, I. K., \& Suartama, I. K. (2020). E-Komik Pendidikan Untuk Membentuk Karakter Dan Meningkatkan Hasil Belajar Siswa Kelas V Pada Mata Pelajaran Bahasa Indonesia. Jurnal Edutech Undiksha, 8(2), 93. https://doi.org/10.23887/jeu.v8i2.28920.

Anugrahana, A. (2020). Hambatan, Solusi dan Harapan : Pembelajaran Daring Selama Masa Pandemi Covid-19 Oleh Guru Sekolah Dasar. Scholaria: Jurnal Pendidikan Dan Kebudayaan, 10(3), 282-289. https://doi.org/10.24246/j.js.2020.v10.i3.p282-289.

Atiyah, U., Miarsyah, M., \& Sigit, D. V. (2020). The Effect of Using E-Learning Based Guided Discovery Learning Model Based on Self-Efficacy Towards Student Learning Outcomes In Biology Class in Reproductive System Subject in High School. International Journal for Educational and Vocational Studies, 2(9), 789-796. https://doi.org/10.29103/ijevs.v2i9.2732.

Azimi, Rusilowati, \& Sulhadi. (2017). Pengembangan Media Pembelajaran IPA Berbasis Literasi Sains untuk Siswa Sekolah Dasar. Pancasakti Science Education Journal, 2(2), 145-157. https://doi.org/http://doi.org/10.24905/psej.v2i2.754.

Balasubramanian, K., Jaykumar, V., \& Fukey, L. N. (2014). A Study on "Student Preference towards the Use of Edmodo as a Learning Platform to Create Responsible Learning Environment. Procedia - Social and Behavioral Sciences, 144. https://doi.org/10.1016/j.sbspro.2014.07.311.

Boyd, L. (2019). Using Technology-Enabled Learning Networks to Drive Module Improvements in the UK OpenUniversity. Journal of Interactive Media in Education, 2019(1), 1-7. https://doi.org/10.5334/jime.529.

Bravo, E. R., Santana, M., \& Rodon, J. (2015). Information systems and performance: The role of 
technology, the task and the individual. Behaviour and Information Technology, 34(3), 247-260. https://doi.org/10.1080/0144929X.2014.934287.

Elfeky, A. I. M., Masadeh, T. S. Y., \& Elbyaly, M. Y. H. (2020). Advance organizers in flipped classroom via elearning management system and the promotion of integrated science process skills. Thinking Skills and Creativity, 35. https://doi.org/10.1016/j.tsc.2019.100622.

Faizah, U., Ambarwati, R., \& Rahayu, D. A. (2021). From offline to online learning: Various efforts to secure the learning process during covid-19 outbreaks. Journal of Physics: Conference Series, 1747(1). https://doi.org/10.1088/1742-6596/1747/1/012002.

Farman, \& Chairuddin. (2020). Pengembangan Media E-Learning Berbasis Edmodo Pada Materi Teorema Pythagoras. AKSIOMA: Jurnal Program Studi Pendidikan Matematika, 9(4), 872-882. https://doi.org/10.24127/ajpm.v9i4.3114.

Fatimah, S., \& Mahmudah, U. (2020). How E-Learning Affects Students' Mental Health During Covid-19 Pandemic: An Empirical Study. Dwija Cendekia: Jurnal Riset Pedagogik, 4(1), 114-124. https://doi.org/10.20961/jdc.v4i1.41991.

Fauzi, I., \& Sastra Khusuma, I. H. (2020). Teachers' Elementary School in Online Learning of COVID-19 Pandemic Conditions. Jurnal Iqra': Kajian Ilmu Pendidikan, 5(1), 58-70. https://doi.org/10.25217/ji.v5i1.914.

Ferdiansyah, F., Ambiyar, A., Zagoto, M. M., \& Putra, I. E. D. (2020). Pemanfaatan Media Pembelajaran Berbasis E Learning dalam Meningkatkan Hasil Belajar pada Matakuliah Media Pembelajaran Musik. KOMPOSISI: Jurnal Pendidikan, Bahasa Dan Seni, 21(1), 63-72. https://doi.org/10.24036/komposisi.v21i1.42098.

Hanifah, H., Supriadi, N., \& Widyastuti, R. (2019). Pengaruh Model Pembelajaran E-learning Berbantuan Media Pembelajaran Edmodo Terhadap Kemampuan Pemecahan Masalah Matematis Peserta Didik. NUMERICAL: Jurnal Matematika Dan Pendidikan Matematika. https://doi.org/10.25217/numerical.v3i1.453.

Haruna, N. A., Setiawan, D. G. E., \& Odja, A. H. (2021). Penerapan E-Learning Menggunakan Media Edmodo dalam Pembelajaran Fisika Berbasis Nilai Karakter untuk Meningkatkan Hasil Belajar pada Konsep Usaha dan Energi. Physics Education Research Journa, 3(1), 65-74. https://doi.org/10.21580/perj.2021.3.1.6737.

Hasanah, I., Sarwanto, S., \& Masykuri, M. (2018). Pengembangan Modul Suhu dan Kalor Berbasis Project Based Learning untuk Meningkatkan Keterampilan Proses Sains dan Kemampuan Berpikir Kritis Siswa SMA/MA. Jurnal Pendidikan (Teori Dan Praktik), 3(1), 38-44. https://doi.org/10.26740/jp.v3n1.p38-44.

Hatip, A., Sucipto, S., \& Setiawan, W. (2019). Pelatihan Penggunaan E-learning Berbasis Media Sosial Edmodo bagi Guru SD Negeri Mulyorejo I Surabaya. Jurnal Pengabdian Dan Penerapan IPTEK, 3(1), 61-68. https://doi.org/10.31284/j.jpp-iptek.2019.v3i1.428.

Helsa, Y., \& Kenedi, A. K. (2019). Edmodo-Based Blended Learning Media in Learning Mathematics. Journal of Teaching and Learning in Elementary Education (Jtlee), 2(2), 107-117. https://doi.org/10.33578/jtlee.v2i2.7416.

Herayanti, L., Habibi, H., \& Fuaddunazmi, M. (2017). Pengembangan Media Pembelajaran Berbasis Moodle pada Matakuliah Fisika Dasar. Jurnal Cakrawala Pendidikan, 36(2), 210-219. https://doi.org/10.21831/cp.v36i2.13077.

Heru, H., \& Yuliani, R. E. (2020). Pelatihan Pengembangan Bahan Ajar Multimedia Pembelajaran Interaktif Berbasis Pendekatan Saintifik Menggunakan Metode Blended Learning bagi Guru SMP/MTs Muhammadiyah Palembang. Jurnal Pengabdian Pada Masyarakat, 5(1), 35-44. https://doi.org/10.30653/002.202051.279.

Jayusman, I., \& Shavab. (2020). Studi Deskriptif Kuantitatif tentang Aktivitas Belajar Mahasiswa dengan Menggunakan Media Pembelajaran Edmodo dalam Pembelajaran Sejarah. Jurnal Artefak, 7(1). https://doi.org/10.25157/ja.v7i1.3180.

Jayusman, Iyus, \& Shavab, O. A. K. (2020). Aktivitas Belajar Mahasiswa Dengan Menggunakan Media Pembelajaran Learning Management System (Lms) Berbasis Edmodo Dalam Pembelajaran Sejarah. Jurnal Artefak, 7(1), 13. https://doi.org/10.25157/ja.v7i1.3180.

Jogezai, N. A., Baloch, F. A., Jaffar, M., Shah, T., Khilji, G. K., \& Bashir, S. (2021). Teachers' Attitudes Towards Social Media (SM) Use in Online Learning Amid The COVID-19 Pandemic: The Effects of SM Use by Teachers and Religious Scholars During Physical Distancing. Journal Heliyon, 7(4), 1-9. https://doi.org/10.1016/j.heliyon.2021.e06781.

Junaedi, S. (2021). Aplikasi Canva Sebagai Media Pembelajaran Daring Untuk Meningkatkan Kemampuan Kreatifitas Mahasiswa Pada Mata Kuliah English For Information Communication And Technology. 
https://doi.org/10.32497/bangunrekaprima.v7i2,\%200ktober.3000.

Khamparia, A., \& Pandey, B. (2017). Impact of interactive multimedia in E-learning technologies: Role of multimedia in E-learning. Enhancing Academic Research With Knowledge Management Principles, April, 199-227. https://doi.org/10.4018/978-1-5225-2489-2.ch007.

Kurniaman, O., \& Noviana, E. (2017). Penerapan Kurikulum 2013 Dalam Meningkatkan Keterampilan, Sikap, Dan Pengetahuan. Primary: Jurnal Pendidikan Guru Sekolah Dasar, 6(2), 389. https://doi.org/10.33578/jpfkip.v6i2.4520.

Kurtz, G., Tsimerman, A., \& Steiner, O. (2014). The Flipped Classroom Answer to Future Learning? European Journal of Open, Distance and E-Learning, 17(2). https://doi.org/10.2478/eurodl-20140027.

Lestari, N. D. (2018). Analisis Penerapan Kurikulum 2013 Dalam Meningkatkan Kualitas Pembelajaran Ekonomi Di Sma Negeri Se-Kota Palembang. Jurnal Neraca: Jurnal Pendidikan Dan Ilmu Ekonomi Akuntansi, 2(1), 68-79. https://doi.org/10.31851/neraca.v2i1.2190.

Maatuk, A. M., Elberkawi, E. K., Aljawarneh, S., Rashaideh, H., \& Alharbi, H. (2021). The CovID-19 Pandemic and E-learning: Challenges and Opportunities from the Perspective of Students and Instructors. Journal of Computing in Higher Education, 1-18. https://doi.org/10.1007/s12528021-09274-2.

Mali, D., \& Lim, H. (2021). How do students perceive face-to-face/blended learning as a result of the Covid19 pandemic? International Journal of Management Education, 19(3), 100552. https://doi.org/10.1016/j.ijme.2021.100552.

Maqableh, M., \& Alia, M. (2021). Evaluation online learning of undergraduate students under lockdown amidst COVID-19 Pandemic: The online learning experience and students' satisfaction. Children and Youth Services Review, 128(1). https://doi.org/10.1016/j.childyouth.2021.106160.

Miraza, R., Jufrida, J., \& Pathoni, H. (2018). Pengembangan Media E-Learning Berbasis Edmodo dengan Pendekatan Saintifik pada Materi Gelombang Bunyi. Jurnal Pendidikan Fisika, 6(3). https://doi.org/10.26618/jpf.v6i3.1397.

Mpungose, C. B. (2021). Lecturers' reflections on use of Zoom video conferencing technology for elearning at a South African university in the context of coronavirus. African Identities. https://doi.org/10.1080/14725843.2021.1902268.

Mulyadin. (2016). Implementasi Kebijakan Pembelajaran Tematik Terpadu Kurikulum 2013 Di SDN Kauman 1 Malang Dan Sd Muhammadiyah 1 Malang. Jurnal Pendidikan Edutama, 3(2), 31 - 48. https://doi.org/10.30734/jpe.v3i2.35.

Mustakim, Trisnaningsih, \& Adha, M. M. (2021). The Effectiveness of Online Collaborative Learning During Covid-19 Pandemic. 513, 256-262. https://doi.org/10.2991/assehr.k.201230.115.

Mustikaningrum, G., Pramusinta, L., Ayu, S., \& Umar, M. (2020). Implementasi Pendidikan Karakter Terintegrasi Kurikulum Dan Metode Pembelajaran Pada Masa Pandemi Covid-19. AULADUNA: Jurnal Pendidikan Dasar Islam, 7(2), 154-164. https://doi.org/10.24252/auladuna.v7i2a5.2020.

Mustofa, R., \& Syafi'ah, R. (2018). Pengembangan Media Pembelajaran Pop Up Book Materi Kenampakan Permukaan Bumi Mata Pelajaran IPA Kelas III SD. ELSE (Elementary School Education Journal), 2, 30-41. https://doi.org/10.30651/else.v2i2.1723.

Pramana, Jampel, \& Pudjawan. (2018). Meningkatkan Hasil Belajar Biologi Melalui E-Modul Berbasis Problem Based Learning. Jurnal Edutech Undiksha, 8(2), 18-32. https://doi.org/10.23887/jeu.v8i2.28921.

Pratiwi, P. H., Nur, H., \& Martiana, A. (2017). Pengembangan Modul Mata Kuliah Penilaian Pembelajaran Sosiologi Berorientasi Hots. Jurnal Cakrawala Pendidikan, 36(2), 201-209. https://doi.org/10.21831/cp.v36i2.13123.

Purwanto, N. (2009). Prinsip-prinsip dan Teknik Evaluasi Pengajaran. Remaja Rosdakarya.

Pustika, R. (2020). Future english teachers' perspective towards the implementation of e-learning in covid-19 pandemic era. Journal of English Language Teaching and Linguistics, 5(3). https://doi.org/10.1371/journal.pone.0248758.

Putri, D. A. H., Ardi, Alberida, H., \& Yogica, R. (2021). Validitas Media Pembelajaran E-Learning Berbasis Edmodo pada Materi Sel untuk Peserta Didik Kelas XI SMA/MA. Journal for Lesson and Learning Studies, 4(2), 230-237. https://doi.org/10.23887/jlls.v4i2.34443.

Qingqing, H. U. (2016). Research on flipped classroom design and implication based on Edmodo platform. 2016 Eighth International Conference on Measuring Technology and Mechatronics Automation (ICMTMA), 528-532. https://doi.org/10.1109/ICMTMA.2016.131.

Restiyani, R. (2014). Profil Pemanfaatan Teknologi Informasi Dan Komunikasi (Tik) Sebagai Media Dan Sumber Pembelajaran Oleh Guru Biologi. EDUSAINS, 6(1), 49-66. https://doi.org/10.15408/es.v6i1.1100. 
Retnawati, H., Hadi, S., \& Nugraha, A. C. (2016). Vocational High School Teachers' Difficulties in Implementing the Assessment in Curriculum 2013 in Yogyakarta Province of Indonesia. International Journal of Instruction, 9(1), 33-48. https://doi.org/10.12973/iji.2016.914a.

Riduwan. (2012). Pengantar Statistika Sosial. Alfabeta.

Sadikin, A., \& Hakim, N. (2019). Pengembangan Media E-Learning Interaktif dalam Menyongsong Revolusi Industri 4. Jurnal Ilmiah Pendidikan Biologi, 5(2), 131-138. https://doi.org/10.22437/bio.v5i2.7590.

Saputra, N., Hikmah, N., Yustitia, V., Saputra, M., Wahab, A., \& Junaedi, J. (2021). Implementation of Online Learning Using Online Media, During the Covid 19 Pandemic. Budapest International Research and Critics Institute (BIRCI-Journal): Humanities and Social Sciences, 4(2), 1802-1808. https://doi.org/10.33258/birci.v4i2.1857.

Sari, D. P., Solihat, A. R., \& R, W. (2019). Developing 21st Century Student Research Skills Through Assement Matrix and Edmodo In Biology Project. Journal of Physics: Conference Series, 1157(2). https://doi.org/10.1088/1742-6596/1157/2/022093.

Sefriani, R., Sepriana, R., Wijaya, I., \& Radyuli, P. (2021). Blended Learning with Edmodo: The Effectiveness of Statistical Learning during the COVID-19 Pandemic. International Journal of Evaluation and Research in Education, 10(1), 293-299. https://doi.org/10.11591/ijere.v10i1.20826.

Shaik Alavudeen, S., Easwaran, V., Iqbal Mir, J., Shahrani, S. M., Ali Aseeri, A., Abdullah Khan, N., Mohammed Almodeer, A., \& Abdullah Asiri, A. (2021). The influence of COVID-19 related psychological and demographic variables on the effectiveness of e-learning among health care students in the southern region of Saudi Arabia. Saudi Pharmaceutical Journal. https://doi.org/10.1016/j.jsps.2021.05.009.

Sofnidar, S., \& Yuliana, R. (2018). Pengembangan Media Melalui Aplikasi Adobe Flash Dan Photoshop Berbasis Pendekatan Saintifik. Jurnal Gentala Pendidikan Dasar, 3(2), 257-275. https://doi.org/10.22437/gentala.v3i2.6761.

Solehana, L., Asrori, A., \& Usman, A. (2019). The Development of E-Learning Teaching Material Based on Edmodo on Basic Competencies of National Integration at Class X of Senior High School. Journal of Education, Teaching And Learning, 4(2). https://doi.org/10.26737/jetl.v4i2.1914.

Sudewa, K. A., Sugihartini, N., \& Divayana, D. G. H. (2021). Pengembangan Media Pembelajaran E-Learning Berbasis Edmodo Dengan Discovery Learning Pada Mata Pelajaran PPKN Kelas VIII Di SMP Lab Undiksha Singaraja. Kumpulan Artikel Mahasiswa Pendidikan Teknik Informatika (KARMAPATI), 10(1), 25. https://doi.org/10.23887/karmapati.v10i1.29407.

Sunarti, Rahmawati, S., \& Wardani, S. (2016). Pengembangan Game Petualangan “Si Bolang” sebagai Media Pembelajaran Tematik untuk Meningkatkan Motivasi dan Prestasi Belajar Siswa Kelas V Sekolah Dasar. Jurnal Cakrawala Pendidikan, 5(1), 58-68. https://doi.org/10.21831/cp.v1i1.8365.

Suni Astini, N. K. (2020). Tantangan Dan Peluang Pemanfaatan Teknologi Informasi Dalam Pembelajaran Online Masa Covid-19. Cetta: Jurnal Ilmu Pendidikan, 3(2), 241-255. https://doi.org/10.37329/cetta.v3i2.452.

Suriadhi, G., Tastra, I. D. K., \& Suwatra, I. I. W. (2014). Pengembangan E-learning Berabasis Edmodo Pada Mata Pelajaran IPA Kelas VIII Di SMP Negeri 2 Singaraja. Jurnal EDUTECH Undiksha, 2(1). https://doi.org/10.23887/jeu.v2i1.3795.

Suyanti, S., Sari, M. K., \& Rulviana, V. (2021). Media Powtoon Untuk Meningkatkan Motivasi Belajar Siswa Sekolah Dasar. Elementary School: Jurnal Pendidikan Dan Pembelajaran Ke-SD-An, 8(2), 322-328. https://doi.org/10.31316/esjurnal.v8i2.1468.

Tegeh, I. M., Simamora, A. H., \& Dwipayana, K. (2019). Pengembangann media video pembelajaran dengan model pengembangan 4D pada mata pelajaran Agama hindu. Jurnal Mimbar Ilmu, 24(2). https: //doi.org/10.23887/mi.v24i2.21262.

Utami, V. U., Ardi, Lufri, \& Fuadiah, S. (2021). Media Pembelajaran E-Learning Berbasis Edmodo pada Materi Sistem Gerak. Journal for Lesson and Learning Studies, 4(2), 217-223. https://doi.org/10.23887/jlls.v4i2.34238.

Virgiana, A., \& Wasitohadi. (2016). Efektivitas Model Problem Based Learning Berbantuan Media Audio Visual Ditinjau Dari Hasil Belajar IPA Siswa Kelas 5 SDN 1 Gadu Sambong - Blora Semester 2 Tahun 2014/2015. Scholaria: Jurnal Pendidikan Dan Kebudayaan, 6(2), 100-118. https://doi.org/10.24246/j.scholaria.2016.v6.i2.p100-118.

Wardoyo, C., \& Article, H. (2016). Developing Learning Media Based on E-Learning on Accounting Subject for Senior High School Students. Dinamika Pendidikan Unnes, 11(2), 84-93. https: //doi.org/10.15294/dp.v11i2.8932.

Weng, S. S., \& Chen, H. C. (2020). Exploring the role of deep learning technology in the sustainable development of the music production industry. Sustainability (Switzerland), 12(2), 1-20. 
https://doi.org/10.3390/su12020625.

Widyaningrum, H. K., Hasanudin, C., Fitrianingsih, A., Novianti, D. E., Saddhono, K., \& Supratmi, N. (2020). The Use of Edmodo Apps in Flipped Classroom Learning. How is the Students' Creative Thinking Ability? Ingénierie Des Systèmes d Inf., 25(1), 69-74. https://doi.org/10.18280/isi.250109.

Windhiyana, E. (2020). Dampak Covid-19 Terhadap Kegiatan Pembelajaran Online Di Perguruan Tinggi Kristen Di Indonesia. Perspektif Ilmu Pendidikan, 34(1), 1-8. https://doi.org/10.21009/pip.341.1.

Yaniawati, R. P. (2013). E-Learning to Improve Higher Order Thinking Skills ( HOTS ) of Students. Journal of Education and Learning, 7(2), 109-120. https://doi.org/10.11591/edulearn.v7i2.225.

Yanti, F. N., Farida, F., \& Sugiharta, I. (2019). Analisis Kemampuan Pemecahan Masalah Matematis: Dampak Blended Learning Menggunakan Edmodo. Desimal: Jurnal Matematika, 2(2), 173-180. https://doi.org/10.24042/djm.v2i2.4035.

Zhang, D., Zhou, L., Briggs, R. O., \& Nunamaker, J. F. (2016). Instructional video in e-learning: Assessing the impact of interactive video on learning effectiveness. Information and Management, 43(1), 15-27. https://doi.org/10.1016/j.im.2005.01.004. 